\title{
Water quality of Narai canal and Balu river of Dhaka City: An impact of industrialization
}

\author{
S. Roy ${ }^{1^{*}}$, L. N. Banna ${ }^{2}$, M. Hossain ${ }^{3}$ and H. Rahman ${ }^{4}$ \\ ${ }^{1}$ Department of Environmental Science, Bangladesh Agricultural University, Mymensingh-2202, Bangladesh \\ ${ }^{2}$ Department of Environmental Science and Resource Management, Mawlana Bhashani Science and Technology \\ University, Tangail-1902, Bangladesh, ${ }^{3}$ Department of Soil Science, Bangladesh Agricultural University, Mymensingh- \\ 2202, Bangladesh and ${ }^{4}$ Department of Textile Engineering, Bangladesh University of Business and Technology, \\ Mirpur-2, Dhaka-1216, "Email: shorov.06@yahoo.com
}

\begin{abstract}
Rapid industrialization around riverside without having proper environmental consideration causes severe water pollution in our country. On accordance with the consecution of this problem the study was conducted to investigate the water quality of Narai canal and Balu river during January to June, 2012. Water quality parameter analysis i.e. color, odor, $\mathrm{pH}$, total dissolved solids (TDS), dissolved oxygen (DO), ammonium $\left(\mathrm{NH}_{4}\right)$ results show that except $\mathrm{pH}$ all exceeded standard limit for domestic water use, irrigation and fish cultivation. The minimum and maximum values of $\mathrm{pH}$, TDS, DO and $\mathrm{NH}_{4}$ were 6.89-7.33, 982-1308 ppm, 0.33-2.12 ppm and 6.79-89.76 ppm, respectively. Present analysis with secondary research data also revealed that this pollution rate is becoming intensified quickly which may pose a great threat in future for human health, ecosystem and sustainable agricultural production. So, Effluent Treatment Plants (ETP) is urgently needed to minimize the concentration of pollutants and ultimately to save the river water of the concerned area.
\end{abstract}

Keywords: Industrial effluent, Waste water, Pollution, TDS, $\mathrm{NH}_{4}$

\section{Introduction}

Dhaka is second polluted mega cities in the world. It is bounded by rivers, inter-connected with canals which have always formed a support for the city residents. In the last few years, unregulated industrial expansion, teeming infrastructures, rural-to-city population migration and ineffective enforcement of environmental regulations have all been proved very disastrous on surface water quality and its results today's Buriganga.

Though Industries are minor users of water in terms of quantity, but have significant impacts on surface water quality. According to Satter and Islam (2005), about $10 \%$ of industries discharge treated effluent and the rest of the industries discharge effluent in the rivers or water body without any treatment or with minimal treatment. Tejgaon metropolitan area is such a type of industrial area where more than 300 industrial units (Roy, 2013) are located and these units dispose about $12000 \mathrm{~m}^{3}$ untreated waste per day (Roy, 2013) which consists residue of soap, dyeing, pharmaceuticals, metals industries etc. Effluent of this industrial area is directly discharged into Begunbari and Narai canal which carries the waste through Balu river and ultimately flows on Sitalakha river which is used in Saydabad water treatment plant for meeting water consumption demand of Dhaka city dwellers. Thus Balu river and its canal system in Dhaka east especially Narai canal is the most polluted area which is responsible for polluting Sitalakha day by day and the ultimate outcome of this pollution is Saydabad water treatment plant's being in threat. Sometimes it pollutes ground water also. This Water quality deterioration is a great concern in this area not only for aquatic environment, but also a threat for human and animal health due to the spread of toxic substances. About $80 \%$ of the diseases in developing countries are related to contaminated water and the resulting death penalty is as much as 10 million per year (Anonymous, 2004). This water is also important for irrigation purposes. Contamination of these industrial and sewerage waste deteriorates the water quality parameters such as $\mathrm{pH}, \mathrm{EC}, \mathrm{DO}, \mathrm{NH}_{4}$ etc. and alters natural processes and natural resource communities. Due to having no central ETP plants or lowering of unit individual ETP plants, pollution concentration is increasing hazardously and threats for environment is also increasing day by day. Though there were some research work done previously on this study area by Rahman et al., (2012) but regular monitoring of those parameters are necessary for estimating the up-to-date level of pollution by which we can be aware of the threats and the problems. Therefore, the objective of this study is to test the water quality of Balu river and Narai cannel to evaluate the current situation of the concerned area. We hope the study will play a vital role in reducing the future pollution trend of the concerned area by enforcing the appropriate steps of environmental management system. 


\section{Materials and Methods}

\section{Study area}

The study area $\left(23.45^{\circ} \mathrm{N} 90.27^{\circ} \mathrm{E}\right)$ was located at the Tajgaon metropolitan area in Dhaka district (Fig. 1). The location was selected as the industrial effluents discharged directly from Tejgaon industrial area into Begunbari and Narai canal which ultimately flows on Sitalakha river via Balu river. Since majority of those industrial units had no ETP plants, Balu river and its canal system are the most polluted area where toxic substances are mixing with water quality in an unscientific manner. Thus regular monitoring of this area is crucial for enforcing the appropriate steps of environmental management system.

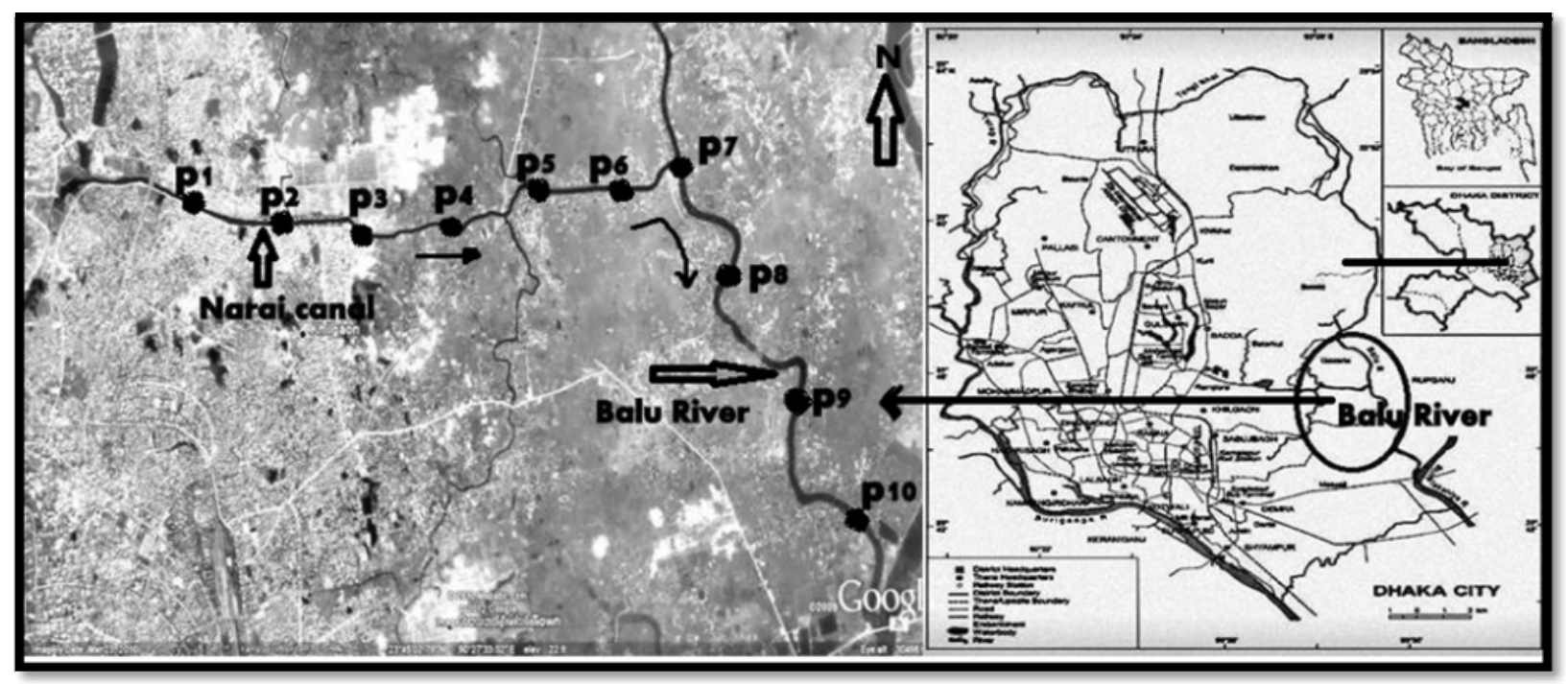

Fig. 1. Study area and sample points (Source: Google Maps, 2012).

\section{Sampling}

The water samples were collected from different points of the Narai canal and Balu River during January to June 2012. From the Narai canal, 3 samples were collected from each of upstream (U) and downstream (D). From Balu river, 2 samples were collected in $500 \mathrm{~mL}$ plastic bottles from each of upstream (U) and downstream (D). Wastewater samples were collected from middle point of the canal or river at 30 to $45 \mathrm{~cm}$ depth from the surface and one kilometer distance between the sampling points. All the sampling bottles were rinsed with wastewater to be sampled prior sampling and sealed immediately after sampling (Huq and Alam, 2005). The samples were analyzed for $\mathrm{pH}, \mathrm{EC}, \mathrm{DO}$ and $\mathrm{NH}_{4}$.

\section{Sample analysis}

Water color was observed by naked eyes and odor was felt with nose. The $\mathrm{pH}$, and total dissolve solids (TDS) were measured on site using $\mathrm{pH}$ meter and TDS meter (HANNA Instruments), respectively. The Dissolved oxygen (DO) was determined by Standard Methods developed by APHA (2005). $\mathrm{NH}_{4}$ concentrations in water were determined by using HACH UV Spectrophotometer DR/ 4000U.

\section{Results and Discussion}

The water color in the sampling sites was light to dark black having bad organic odor, not at all suitable even for aquatic organisms. Phytoplankton enriched dark greenish blue, red or brown color is good for fishes (Das, 1997). Noxious smell indicates extreme level of pollution in the river water. Therefore, the water in Balu river and Narai canal is not suitable for aquaculture, agricultural and domestic purposes. 
The $\mathrm{pH}$ of the 10 sampling points of Narai canal and Balu river ranged from 6.89 to 7.33 (Table 1). A marked change in water $\mathrm{pH}$ has been recognized when comparing with water $\mathrm{pH}$ data (Rahman and Hadiuzzaman, 2005). This is an indicator of water quality deterioration over time. The $\mathrm{pH}$ of water samples from the present study were within the range of both domestic water (De, 2005) and fish culture standard (Meade, 1998), reflecting its suitability for aquatic life and for all types of water uses.

The TDS at different sampling points ranged $982-1308 \mathrm{mg} / \mathrm{L}$ (Table 1). All the sampling points represent the higher TDS value except P10 (Table 1). It is also observed from the study comparing with secondary data that within 7 year (2005- 2012) this TDS value has increased dramatically specially in Narai canal which is highly hazardous for agriculture and a sustainable environment (Fig. 2). The higher the TDS, the higher the salinity of the water and this salinity could also be a major limiting factor for crop yield in poorly drained soils if saline water is used for irrigation (Patel et al., 2002). The similar fact was reported for the Kanafuli River of Bangladesh by Jashimuddin (1993).

Estimates by FAO indicate that of the 250 million hectares of irrigated land in the world, approximately $50 \%$ already show salinization and soil saturation problems, and 10 million hectares are abandoned annually due to these problems (Chowdhury, 1994). The excessive amounts of salts provided by irrigation waters can have unfavorable effects on the chemical, physical and biological properties of the soils (Tejada, and Gonzalez, 2005). These effects include mineralization of the carbon and nitrogen and the enzymatic activity, which is vital for the decomposition of organic matter and necessary for bringing sustainability in production (Wong et al., 2008).

Table 1. Water quality parameters at sampling sites of Narai canal and Balu river

\begin{tabular}{|l|c|c|c|c|c|c|c|c|c|c|c|}
\hline \multirow{2}{*}{$\begin{array}{l}\text { Water quality } \\
\text { parameters }\end{array}$} & \multicolumn{4}{|c|}{ Narai canal (Sampling points) } & \multicolumn{3}{c|}{ Balu river (Sampling points) } & $\begin{array}{c}\text { Range } \\
\text { (Narai canal }\end{array}$ \\
\cline { 2 - 15 } & \multicolumn{3}{|c|}{ Narai canal (u/s) } & \multicolumn{2}{c|}{ Narai Canal (d/s) } & \multicolumn{2}{c|}{ Balu river (u/s) } & \multicolumn{2}{c|}{ Balu river (d/s) } \\
(N1 & $\mathrm{P} 2$ & $\mathrm{P} 3$ & $\mathrm{P} 4$ & $\mathrm{P} 5$ & $\mathrm{P} 6$ & $\mathrm{P} 7$ & $\mathrm{P} 8$ & $\mathrm{P} 9$ & $\mathrm{P} 10$ & Balu river) \\
\hline TDS (mg/L) & 1308 & 1288 & 1105 & 1106 & 1103 & 1101 & 1015 & 1010 & 1006 & 982 & $982-1308$ \\
\hline $\mathrm{pH}$ & 7.03 & 6.89 & 7.08 & 7.22 & 7.25 & 7.33 & 7.33 & 7.33 & 7.31 & 7.28 & $6.89-7.33$ \\
\hline $\mathrm{NH}_{4}(\mathrm{mg} / \mathrm{L})$ & 89.76 & 64.48 & 49.38 & 42.57 & 47.63 & 36.31 & 27.58 & 22.47 & 14.45 & 6.79 & $6.79-89.76$ \\
\hline $\mathrm{DO}(\mathrm{mg} / \mathrm{L})$ & 0.45 & 0.37 & 0.33 & 0.38 & 0.35 & 0.34 & 0.37 & 1.21 & 1.66 & 2.12 & $0.33-2.12$ \\
\hline
\end{tabular}

Dissolved oxygen refers to the oxygen gas that is dissolved in the water and made available to aquatic life. Oxygen gets into the water by diffusion from the surrounding air, by aeration from moving water or as a product of photosynthesis. Dissolved oxygen is one of the most important water quality parameters, requires continuous monitoring in aquaculture production systems. This is due to the fact that fish aerobic metabolism requires dissolved oxygen (Timmons, 2001). Without free dissolved oxygen (DO), the rivers, streams and lake become inhabitable to gill breathing aquatic organisms (Vaselina, 1990). The average value of DO levels $(6.5 \mathrm{mg} / \mathrm{l})$ indicates the average quality of river water (APHA, 2005). Whereas the DO values were recorded ranging from 0.33 to $2.12 \mathrm{ppm}$ at different points. The lowest mean value $(0.36$ ppm) was observed in Narai canal (d/s). Not only analyzed data but also the previous data on the water quality of the Balu river suggested that the Balu river was heavily polluted with organic and human wastes, as indicated by the low DO and high values of coliform. The DO concentrations in the Balu river had been much below the critical level of $4 \mathrm{mg} / \mathrm{L}$ since 1989 (DoE, 2003). When the DO levels are lower than standard values the growth of the fish can be highly affected by an increase in stress, tissue hypoxia, and a decrease in swimming activities and reduction in immunity to diseases. Other some problem e.g. respiration and feeding activities also decrease with lowering of dissolved oxygen even fish mortality is possible in the case of higher reduction of DO values which was observed in this study area. DO levels below $1 \mathrm{ppm}$ will not support fish; below $2 \mathrm{ppm}$ may lead to the death of most fishes. DO values should be above $6.0 \mathrm{ppm}$ for drinking water and more than $5.0 \mathrm{ppm}$ is suggested for fisheries, recreation and irrigation (DoE, 1997). So our study suggests that this value is totally unsuitable to support the fish life in this water body. This situation defines why this river was nearly lifeless. 
The ammonium $\left(\mathrm{NH}_{4}\right)$ at different sampling points ranged from $6.79-89.76 \mathrm{mg} / \mathrm{L}$ and most of the point showed above or near $30 \mathrm{mg} / \mathrm{L}$ (Table 2). It is also observed from the study that within 7 years (20052012) this ammonium value has increased dramatically specially in Narai canal which is highly hazardous for agriculture and a sustainable environment (Fig. 2). According to Ayers \& Westcot (1976) most crop yields are generally unaffected until nitrogen concentrations in irrigation water exceed $30 \mathrm{mg} / \mathrm{L}$. So this level is so high compared to safe limit. Plants generally have a high nitrogen demand during the early growth stages so higher amount of nitrogen is good for vegetable cultivation. It also creates weed problems. However, excessive concentrations during the later flowering and fruiting stages may cause yield losses. So higher concentration of ammonium may be suitable for irrigating vegetables but long time irrigation may cause harm for grain cultivation.

Table 2. Scenario of the evaluation of resulting value of mean water quality parameters with secondary data and standard values

\begin{tabular}{|c|c|c|c|c|c|c|}
\hline \multicolumn{2}{|c|}{ Water quality parameters } & \multirow{3}{*}{$\begin{array}{c}\text { Mean } \\
(2012) \pm \text { S.E. } \\
1168.5 \pm 41 \\
10033+7\end{array}$} & \multirow{3}{*}{$\begin{array}{c}\begin{array}{c}\text { USPH domestic water } \\
\text { supplies standard }{ }^{\mathrm{a}}(\mathrm{mg} / \mathrm{L})\end{array} \\
500\end{array}$} & \multirow{3}{*}{$\begin{array}{l}\begin{array}{l}\text { Standard for } \\
\text { fish culture }\end{array} \\
<400\end{array}$} & \multirow{3}{*}{$\begin{array}{l}\text { Standard for } \\
\text { irrigation }^{\text {, e }}\end{array}$} & \multirow{3}{*}{$\begin{array}{c}\begin{array}{c}\text { Drinking water } \\
\text { standard }^{\mathrm{d}}\end{array} \\
1000\end{array}$} \\
\hline \multirow[t]{2}{*}{ TDS (mg/L) } & Narai canal & & & & & \\
\hline & Balu River & & & & & \\
\hline \multirow[t]{2}{*}{$\mathrm{pH}$} & Narai canal & $7.1 \pm 0.04$ & \multirow[t]{2}{*}{$6.5-8.5$} & \multirow[t]{2}{*}{$6.5-8.0$} & \multirow[t]{2}{*}{$6.5-8.5$} & \multirow[t]{2}{*}{$6.5-8.5$} \\
\hline & Balu River & $7.3 \pm 0.08$ & & & & \\
\hline \multirow[t]{2}{*}{$\mathrm{NH}_{4}(\mathrm{mg} / \mathrm{L})$} & Narai canal & $55.02 \pm 7.93$ & \multirow[t]{2}{*}{0.5} & \multirow[t]{2}{*}{1.0} & \multirow[t]{2}{*}{ NA } & \multirow[t]{2}{*}{0.05} \\
\hline & Balu River & $17.82 \pm 4.56$ & & & & \\
\hline \multirow[t]{2}{*}{$\mathrm{DO}(\mathrm{mg} / \mathrm{L})$} & Narai canal & $0.37 \pm 0.01$ & \multirow[t]{2}{*}{$4.0-6.0$} & \multirow[t]{2}{*}{5.0} & \multirow[t]{2}{*}{5.0} & \multirow[t]{2}{*}{ NA } \\
\hline & Balu River & $1.34 \pm 0.20$ & & & & \\
\hline
\end{tabular}

Note: $\mathrm{NA}=$ Not Available, S.E. $=$ Standard error mean, $\mathrm{USPH}=$ United States Public Health, and ADB $=$ Asian Development Bank (Source: 'De, 2005; ${ }^{\mathrm{b}}$ Meade , 1998; ' ${ }^{\mathrm{C}}$ Ayers and Westcot, 1976; ${ }^{\mathrm{d} A D B}, 1994 ;{ }^{\mathrm{e}} \mathrm{DoE}, 1997$ ).

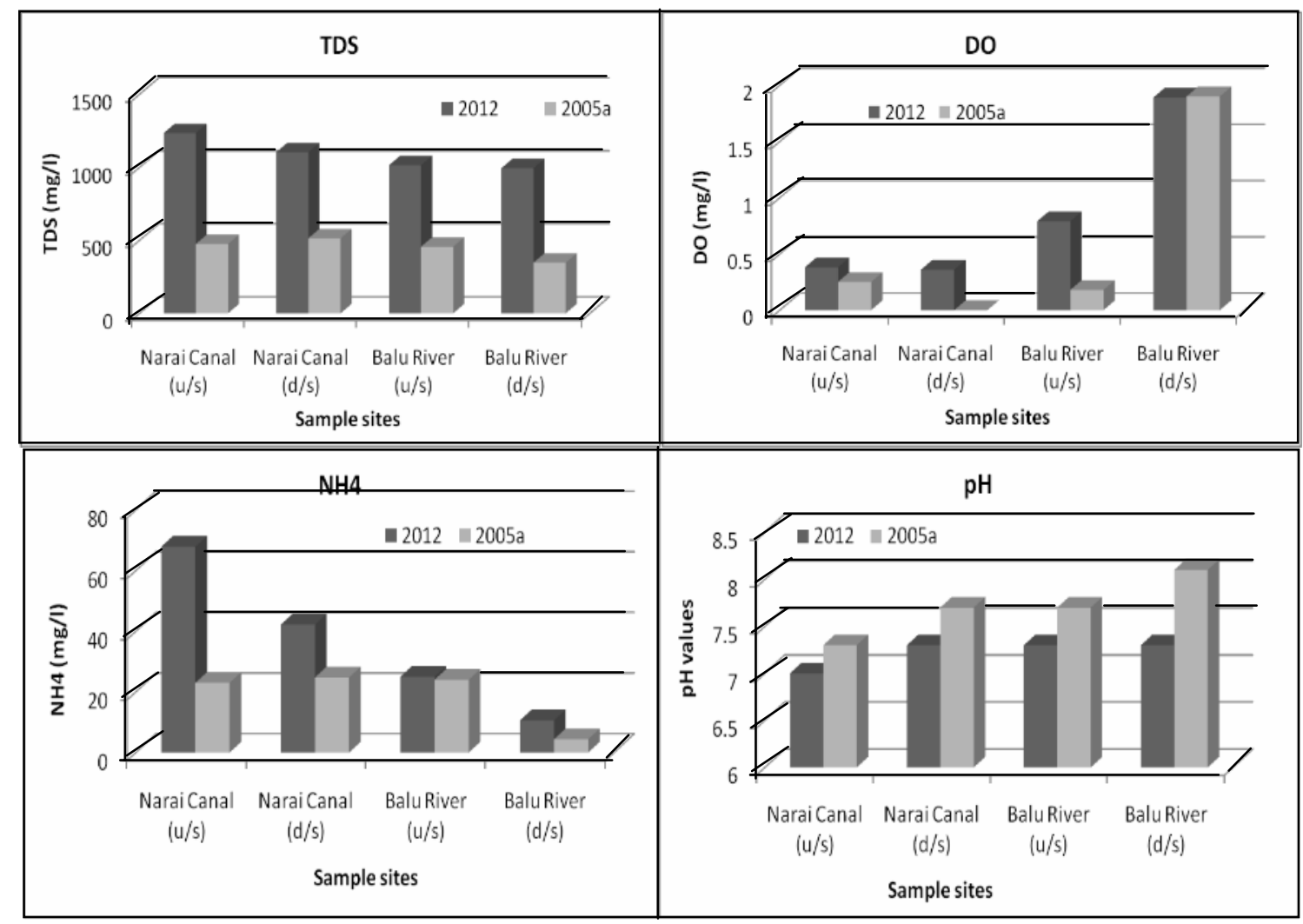

Note: ${ }^{\mathrm{a}}$ Rahman and Hadiuzzaman, 2005

Fig. 2. Changes in water quality of Balu river in the last seven years (2005-2012) 
$\mathrm{NH}_{4}$ concentration above $0.05 \mathrm{ppm}$ is not only vulnerable for human health (ADB, 1994) but also detrimental for aquaculture. This will have a ripple effect on other attributes of water quality, such as increasing biochemical oxygen demand and lowering dissolved oxygen levels which can also be lowered when $\mathrm{NH}_{4}-\mathrm{N}$ is high due to increased nitrification. If enough nutrients are present, eutrophication may occur. When there is such an abundance of nutrients available in water there will be a significant increase in plant and algal growth. As these organisms die, they will accumulate on the bottom and decompose, releasing more nutrients and compounding the problem. In some cases, this process of eutrophication can become so advanced that the body of water may become a marsh, and eventually fill in completely. It results higher pollution and fish death. So respecting all of these values we may say this water is highly vulnerable for environment.

\section{Conclusion}

The results of this study have revealed that both the Narai canal and Balu river water were neutral with suitable $\mathrm{pH}$ value. On the other hand, in most of the points the values of other three parameters, i.e. TDS, $\mathrm{DO}$ and $\mathrm{NH}_{4}$ were found to be highly vulnerable condition comparing with the standard values along with the antique situation. This water is not only detrimental for human health and aquaculture but also unsuitable for irrigation practices. Under such conditions, our recommendations are: (i) appropriate distance from the surrounding water body should be maintained for waste dumping and dumping site should be properly managed (ii) industries should install and operate effluent treatment plant (ETP) for all the industrial wastes so that they are treated before being dumped into the environment and (iii) appropriate rules and legislation on dumping of industrial waste into the river should be established and implemented strictly.

\section{References}

ADB (Asian Development Bank). 1994. Training Manual for Environmental Monitoring, USA: Engineering Science Inc., 2-16 and 10.

Anonymous. 2004. Water: A Millennial Priority, The Acme Agrovat and Beverage Ltd., Dhaka, Bangladesh.

APHA (American Public Health Association). 2005. Standard Methods for the Examination of Water and Wastewater, 20 ${ }^{\text {th }}$ Edition, Washington DC, USA: American Public Health Association.

Ayers, R.S. and Westcot, D.W. 1976. Water Quality for Agriculture" FAO Irrigation and Drainage Paper, 29(1).

Chowdhury, N.K. 1994. Study on the effects of effluents discharged from the KPRC on the water quality with the preview of pollution status of the Karnafuli River, Chittagong. M.Sc Dissertation, Institute of Marine Science, University of Chittagong, Bangladesh, 1-87.

Das, B. 1997. Fisheries and fisheries resources management in Bangladesh, Bangla Academy, 153-155.

De, A.K. 2005. Environmental Chemistry, Fifth Edition. India: New Age International Publishers, 242.

DoE (Department of Environment). 1997. Environmental quality standards (EQS) for Bangladesh, Dhaka: GOB.

DoE (Department of Environment), 2003. Fourth Dhaka Water Supply Project, Dhaka Water Resource Management Programme, Department of Environment, Dhaka, Bangladesh.

Huq, S.M.I. and Alam, M.D. 2005. A Handbook on Analysis of Soil, Plant and Water, BACER-DU, University of Dhaka, Bangladesh, 31-37 and 201-210.

Jashimuddin, S.M. 1993. Environmental impact assessment of the municipal sewage discharge through Majhirghat canal on the Karnafuli River water, M.Sc. Dissertation. Institute of Marine Science, University of Chittagong. Bangladesh, 1-79.

Meade, J.W. 1998. Aquaculture Management, India: CBS Publishers \& Distributors: 9.

Patel, R., Prasher, S., Bonnell, R. and Boughton, R. 2002. Development of comprehensive soil salinity index, J. of Irrigation and Drainage Engineering-ASCE, 128. 185-188.

Rahman, A., zafor, M.A. and shantanu, K. 2012. Analysis and comparision of surface water quality parameters in and around dhaka city international journal of civil engineering and technology(ijciet), 3(2):7-15. 
Rahman, M.D. and Hadiuzzaman, M. 2005. A Bachelor of Science Thesis on Pollution Status and Trends in water quality of Shitalakhya and Balu Rivers, University of Engineering and Technology, Chapter 3, Present Status of Balu and Shitalakhya River.

Roy,S., Banna, L.N. and Mamun, S.A.Farukh, M.A. 2013. Effects of Industrial Waste water reuse for crop production: A case study in Tejgaon metropolitan area of Dhaka, Bangladesh, J. Bangladesh Agril.Univ.11(2): 183-188.

Satter, M.A. and Islam, M.S. 2005. Quality Assessment of River Water around Dhaka City, Bangladesh Journal of Environmental Sciences, 10. 326-329.

Tejada, M. and Gonzalez, J.L. 2005. Beet vinasse applied to wheat under dry land conditions affects soil properties and yield, European Journal of Agronomy, 23(4). 336-347.

Timmons, M.B., James, M.E., Fred, W.W., Sreven, T.S. and Brian, J.V. 2001. Recirculating Aquaculture Systems, NRAC publication, 01.

Vaselina, P.A., Peirce, J.J. and Weiner, R.F. 1990. Environmental Pollution and Control, 389.

Wong, V.N.L., Dalal, R.C. and Greene, R.S.B. 2008. Salinity and sodicity effects on respiration and microbial biomass of soil. Biology and Fertility of Soils, 44 (7). 943-953. 